\title{
Occurrence of Clostridium perfringens vegetative cells and spores throughout an industrial production process of black soldier fly larvae (Hermetia illucens)
}

\author{
N. Van Looveren ${ }^{1,2}$ iD, D. Vandeweyer ${ }^{1,2}$, J. van Schelt ${ }^{3}$ and L. Van Campenhout ${ }^{1,2 *}$ \\ ${ }^{1}$ KU Leuven, Department of Microbial and Molecular Systems (M⿻25), Lab4Food, Geel Campus, 2440 Geel, Belgium; \\ ${ }^{2}$ KU Leuven, Leuven Food Science and Nutrition Research Centre (LFoRCe), Leuven, Belgium; ${ }^{3}$ Bestico B.V., 2651 BE Berkel \\ en Rodenrijs, the Netherlands; leen.vancampenhout@kuleuven.be
}

Received: 27 April 2021 / Accepted: 28 July 2021

(c) 2021 Wageningen Academic Publishers

OPEN ACCESS CC (i) RESEARCH ARTICLE

\begin{abstract}
The main use of black soldier fly larvae (Hermetia illucens) is currently as an animal feed ingredient. While the bacterial community of the larvae has been characterised repeatedly via sequencing, microbiological safety assessment based on culture-dependent techniques is still scarce. This study focused on the occurrence of the spore-forming foodborne pathogen Clostridium perfringens during rearing and consecutive processing of the larvae, based on observations in a single rearing facility. C. perfringens vegetative cells and spores were determined, in addition to total viable counts, total aerobic spore counts and intrinsic parameters including $\mathrm{pH}$, water activity and moisture content. All samples were obtained from an industrial production plant. In a preliminary experiment, substrate ingredients and dried larvae were analysed, but the larvae were produced with a previous batch of the substrate mixture. A second, more detailed, experiment was performed where all samples were collected sequentially from the same production run (substrate ingredients, substrate mixture, starting larvae, harvested larvae, residue, dried larvae and stored dried larvae). In the two experiments, (presumptive) C. perfringens, as determined on tryptose sulphite cycloserine agar, was found at low numbers in the ingredients and in the second experiment it was also found in the substrate mixture. Over the two experiments, total C. perfringens counts (i.e. vegetative cells plus spores) ranged between $3.0 \pm 0.1$ and $<1.2 \pm 0.5 \mathrm{log} \mathrm{cfu} / \mathrm{g}$ and $C$. perfringens spores ranged between $2.5 \pm 0.1$ and $<1.0 \pm 0.0$ $\log \mathrm{cfu} / \mathrm{g}$. Interestingly, vegetative cells and spores of C. perfringens were below the detection limit in all larvae samples. Therefore, it appears that at this production site and based on the samples investigated, the pathogen did not colonise the larvae. However, these results indicate that insect producers should monitor this pathogen among others, and install good hygiene practices to avoid contamination.
\end{abstract}

Keywords: black soldier fly larvae, Hermetia illucens, production process, Clostridium perfringens, microbiological safety

\section{Introduction}

As the demand for animal feed sources rises, insects are increasingly considered as a sustainable protein rich feed source (Stamer, 2015; Vandeweyer et al., 2021; Wang and Shelomi, 2017). Black soldier fly larvae (Hermetia illucens L., Diptera: Stratiomyidae) are known for their interesting nutritional value for animals, growth potential on various organic waste streams, high bioconversion ratio and low environmental impact (Diener et al., 2009; Joosten et al., 2020; Lievens et al., 2021; Makkar et al., 2014; Oonincx et al., 2015). While in Europe, Regulation (EC) No 2017/893
(EC, 2017) allows the use of black soldier fly larvae (BSFL) in aquafeed, the use of processed larvae in ruminants and monogastric animals is still prohibited at this moment by the EU feed ban or Regulation (EC) No 999/2001 (EC, 2001). Nevertheless, the European Commission is investigating the possibility to revise the feed ban and authorise insect proteins in pig and poultry feed in the future (IPIFF, 2021). Regulation (EC) No 142/2011 (EC, 2011) describes specific methods that should be applied for processing insects intended for animal feed, or insect producers can apply alternative methods (so-called 'method 7 '), as long as they can demonstrate in samples taken directly after 
the treatment that Clostridium perfringens is absent in $1 \mathrm{~g}$ samples of the final product, taken on a daily basis over a period of 30 production days. Also for Salmonella and Enterobacteriaceae, this regulation contains criteria for the case insect producers develop their own processing method.

As reported in several studies, BSFL can be contaminated with a wide range of food pathogens, such as Salmonella, Bacillus cereus and some species of the genera Campylobacter, Listeria and Clostridium (Jiang et al., 2019; Raimondi et al., 2020; Wu et al., 2020; Wynants et al., 2019). Because of their heat resistant spore-forming properties, the genera Bacillus and Clostridium are considered to be of major concern (Grenda et al., 2021; Vandeweyer et al., 2021). One of the most relevant Clostridium species related to insects and concerning human and animal health is C.perfringens, a Gram-positive, anaerobic, spore-producing bacterium (Bagge et al., 2010; Talukdar et al., 2017; Vandeweyer et al., 2021), which causes a broad spectrum of diseases, but most typically enteritis (Li et al., 2016). After ingestion of a large number of vegetative $C$. perfringens cells $\left(10^{6}-10^{7}\right.$ cells/g), food poisoning is usually caused by enterotoxin production that occurs during sporulation in the small intestine (Juneja et al., 2010; McNamara and Lattuade, 1998). If C. perfringens occurs in animal feed ingredients such as BSFL, most likely in the form of spores, the pathogen can possibly enter the food chain. Hence, while the actual cause of disease in humans is the uptake of a large number of vegetative cells of $C$. perfringens via the food, the spores likely play a role in transmission of the pathogen from the early stages in the food chain, such as feed ingredients.

The microbiota of BSFL has been intensively investigated recently (Vandeweyer et al., 2021), but there are some limitations with respect to microbiological safety assessment. The first limitation is that so far, research mainly focuses on the rearing phase. Post-harvest processing, including steps that potentially either reduce or increase the microbial load, is rarely included. Secondly, most papers describe a characterisation that relies on sequencing the microbiome, and mostly only the bacterial community. This approach relies on the DNA of micro-organisms present, and therefore its value for evaluating the microbiological safety of samples is limited. Indeed, present DNA can originate from dead cells, leading to a false positive result. Conversely, processing technologies can destroy DNA so that an organism is not recovered during sequencing, but toxins that might have been produced by the organism may still be active. In addition, in BSFL bacterial spores have been shown to be difficult to detect via sequencing (Filippidou et al., 2015; Wynants et al., 2019). In this way, a microbiological safety problem may be underestimated when based on sequencing only.

The aim of this study was to obtain insight in the relevance of a specific food pathogen, C. perfringens, for BSFL. The research was conducted on samples related to rearing as well as processing of BSFL in an industrial production facility. Moreover, culture-dependent techniques were applied, and total counts (including vegetative cells and endospores) as well as endospores alone were determined in parallel. The aim was to observe whether C. perfringens was present or not in the production process, and if so, in which phase(s) of the process and at what quantities, to evaluate the possible risk of a microbiological problem caused by the pathogen.

\section{Materials and methods}

\section{BSFL production process, experimental set-up and sampling}

The BSFL production process of the rearing facility under study is schematically presented in Figure 1 . Three substrate ingredients, being potato starch, a wheat-andpotato-processing-product (WPPP) and protein kibbles, were mixed to prepare the insect rearing substrate, called substrate mixture. Ingredients were commercially available feed products and GMP + certified (GMP is the abbreviation of good manufacturing practices and the ' + ' means that HACCP, or hazard analysis and critical control points, is also included). The rearing cycle started with the addition of one week old starter larvae of approximately $10 \mathrm{mg}$ to the substrate mixture and ended after one week with the harvesting of final stage larvae of approximately $100 \mathrm{mg}$, yielding a residue stream, also called frass. Next, a drying process of $125{ }^{\circ} \mathrm{C}$ for 45 minutes was applied to the harvested larvae. These dried larvae were stored in big plastic bags at room temperature.

The first experiment (Experiment 1) was set up as a batch-independent experiment to obtain an indication of the occurrence of $C$. perfringens by collecting samples from only the individual substrates (potato starch, WPPP and protein kibbles) and the dried larvae. These samples were collected from different production runs in the insect rearing company. To gain more insight related to the consecutive steps during production, a subsequent experiment (Experiment 2) was executed several weeks later to collect sequential samples from the same insect batch during a single production run. This sample set consisted of the three substrate ingredients and the corresponding substrate mixture, the starter and final harvested larvae reared on that substrate mixture, the dry residue after sieving the larvae out ('frass') and the dried larvae (immediately after drying as well as after two weeks of storage at room temperature). In total, thirteen different samples (four for Experiment 1 and nine for Experiment 2) were taken and at least $50 \mathrm{~g}$ per sample were shipped to the laboratory at ambient temperature. Samples were immediately analysed upon arrival with respect to intrinsic parameters and microbial counts. 


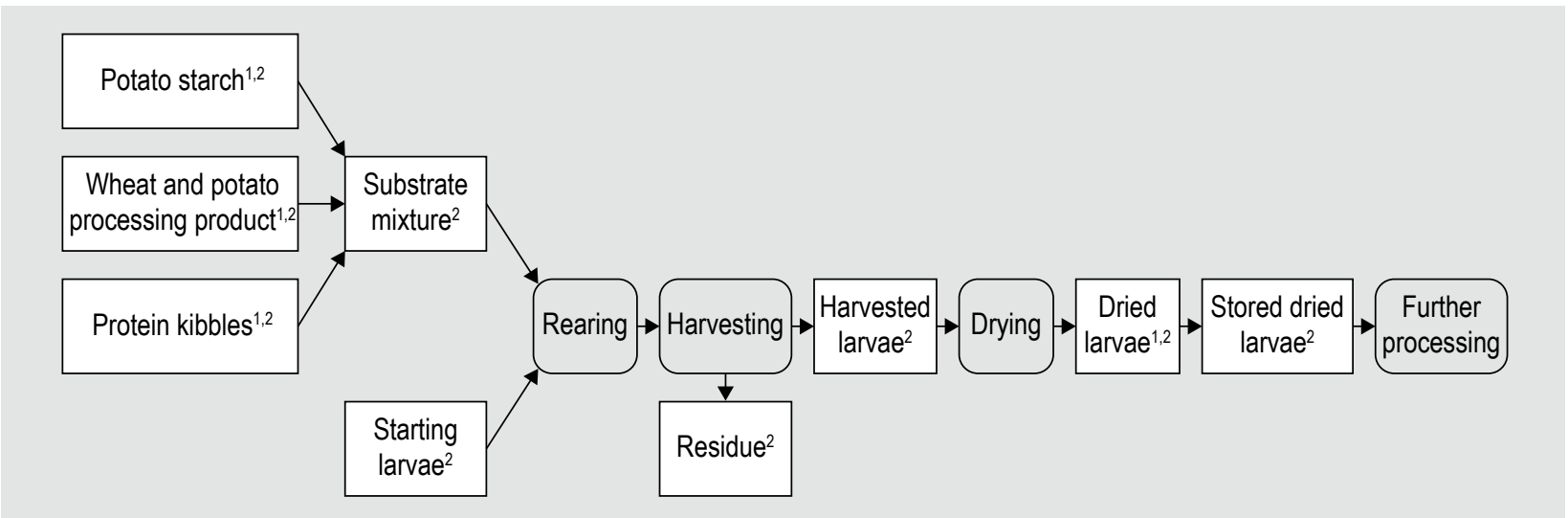

Figure 1. Production process of dried black soldier fly larvae. White boxes represent samples taken, grey boxes represent process steps. The superscript next to a sample type refers to the experiment in which that type of sample was taken (Experiment 1 or 2).

\section{Intrinsic parameters}

All samples were subjected to measurement of $\mathrm{pH}$, water activity $\left(\mathrm{a}_{\mathrm{w}}\right)$ and moisture content. For $\mathrm{pH}$ measurement, a digital pH meter (Portamess 911, Knick, Berlin, Germany with SI analytics electrode, Mainz, Germany) was used at room temperature. For dry samples, $17 \mathrm{ml}$ demineralised water was added to $10 \mathrm{~g}$ of the sample before $\mathrm{pH}$ measurement, based on the method of Meneguz et al. (2018). Water activity was determined using a water activity meter (LabMaster $\mathrm{a}_{\mathrm{w}}$, Novasina, Lachen, Switzerland), as soon as the water activity and temperature $\left(25^{\circ} \mathrm{C}\right)$ were stable for $5 \mathrm{~min}$. Moisture content was calculated by the difference in weight of $5 \mathrm{~g}$ of the sample before and after overnight oven drying at $105{ }^{\circ} \mathrm{C}$. All measurements of $\mathrm{pH}, \mathrm{a}_{\mathrm{w}}$ and moisture content were performed in triplicate (technical replicates).

\section{Microbiological analyses}

Microbiological plate counts were performed using the pour-plate method according to the ISO standards as described by Dijk et al. (2015). Five grams of each sample were diluted with $45 \mathrm{~g}$ of peptone physiological salt solution $(0.85 \% \mathrm{NaCl}, 0.1 \%$ peptone, Biokar Diagnostics, Beauvais, France) to obtain a primary dilution, followed by a homogenisation for $60 \mathrm{~s}$ in a stomacher (BagMixer, Interscience, Saint Nom, France). For larvae samples, the larvae were pulverised in the liquid using a hand held kitchen mixer for one minute (Ergomixx, Bosch, Gerlingen, Germany), resulting in a homogeneous mixture, prior to homogenisation in the stomacher. In between samples, the mixer was cleaned with water to remove the remains of the mixed sample, followed by a disinfection step with ethanol and flame sterilisation. From the primary dilution, a tenfold dilution series was plated on different media. Total viable aerobic counts were determined on plate count agar (PCA; Biokar Diagnostics) after incubation for $72 \mathrm{~h}$ at $30^{\circ} \mathrm{C}$. For the determination of (presumptive) total
C. perfringens counts, the dilution series was plated on tryptose sulphite cycloserine agar (TSC; Biokar Diagnostics) supplemented with D-cycloserine $(200 \mathrm{mg} / 500 \mathrm{ml}$ TSC; Biokar Diagnostics) and incubated anaerobically for $24 \mathrm{~h}$ at $37^{\circ} \mathrm{C}$, according to ISO 7937:2004. For determination of bacterial endospores, the $10^{-1}$ dilution was subjected to a heat shock $\left(80^{\circ} \mathrm{C}\right.$ for $\left.10 \mathrm{~min}\right)$ to kill vegetative cells and to activate the endospores, followed by the preparation of a tenfold dilution series, plating on PCA for aerobic bacterial endospores and on TSC for C. perfringens endospores, and aerobic and anaerobic incubation, respectively, for $24 \mathrm{~h}$ at $37^{\circ} \mathrm{C}$. Anaerobic conditions were created by using anaerobic jars (VWR, Leuven, Belgium), anaerobic gas generating sachets (Oxoid Anaerogen 2.51 Sachet, Thermo Fisher Scientific, Merelbeke, Belgium) and anaerobic indicator strips (Oxoid Resazurin Anaerobic Indicator, Thermo Fisher Scientific). For each of the samples, three technical replicates were analysed and all plating was performed in duplicate to calculate the average and standard deviations, expressed in $\log \mathrm{cfu} / \mathrm{g}$.

\section{Statistical analysis}

To determine statistical differences in intrinsic parameters and microbial counts between different samples within Experiment 1 and 2, data were analysed using R v4.0.3 (R Development Core Team, Vienna, Austria). One-way ANOVA was used, followed by a Tukey HSD post-hoc test. For all statistical analyses, the significance level was set at 0.05 (R Development Core Team, 2020).

\section{Results}

\section{Experiment 1}

Intrinsic parameters and microbial counts for the potato starch, the WPPP, the protein kibbles and the dried larvae, analysed in Experiment 1, are shown in Table 1. For all three substrates, the $\mathrm{pH}$ was equal to or below 5.02 . The potato 
starch and the WPPP were both characterised with a high water activity of $0.97 \pm 0.00$ and a high moisture content $(81.3 \pm 0.0 \%$ and $80.4 \pm 1.4 \%$, respectively). The protein kibbles, a dried product, evidently showed a lower water activity of $0.56 \pm 0.00$ and moisture content of $10.9 \pm 0.1 \%$. For the dried larvae, a near-neutral $\mathrm{pH}$ of $6.90 \pm 0.01$, a water activity of $0.22 \pm 0.01$ and a moisture content of $2.1 \pm 0.0 \%$ were obtained.

While the total viable count did not considerably differ between the three substrate ingredients, the WPPP showed a significantly lower number of aerobic endospores $(2.3 \pm 0.3$ $\log \mathrm{cfu} / \mathrm{g})$ compared to the potato starch $(3.8 \pm 0.0 \log \mathrm{cfu} / \mathrm{g}$, $P<0.001)$ and protein kibbles $(3.6 \pm 0.3 \log \mathrm{cfu} / \mathrm{g}, P<0.001)$. The same trend can be observed for the total C. perfringens count (i.e. vegetative cells plus spores) and the $C$. perfringens endospore count (i.e. spores alone). For potato starch and protein kibbles, comparable values above the detection limit of $1.0 \pm 0.0 \log \mathrm{cfu} / \mathrm{g}$ were observed for total $C$. perfringens (2.3 \pm 0.3 and $2.0 \pm 0.0 \log \mathrm{cfu} / \mathrm{g}$, respectively, $P=0.688)$ and C. perfringens endospores $(1.4 \pm 0.1$ and $1.3 \pm 0.3 \mathrm{log} \mathrm{cfu} / \mathrm{g}$, respectively, $P=0.829$ ). In contrast, for the WPPP only one of the three replicates showed a total C. perfringens count above the detection limit, resulting in an average total C. perfringens count of $<1.2 \pm 0.5 \mathrm{log} \mathrm{cfu} / \mathrm{g}$. The C. perfringens endospore count was below the detection limit for all replicates $(<1.0 \pm 0.0 \mathrm{cfu} / \mathrm{g})$. Since plate counting was used in the microbiological analyses, it cannot be stated that an organism is completely absent when no colonies at all are present on the plates. For the dried larvae, the total viable count and the endospore count $(4.3 \pm 0.7$ and $3.9 \pm 0.1 \log \mathrm{cfu} / \mathrm{g}$, respectively) did not show a statistically significant difference from the counts for potato starch $(P=0.434$ and $P=0.977)$ and protein kibbles $(P=0.999$ and $P=0.266)$. Furthermore, the total $C$. perfringens counts as well as the $C$. perfringens endospore counts were below the detection limit of $1.0 \pm 0.0 \mathrm{cfu} / \mathrm{g}$.

\section{Experiment 2}

For Experiment 2, with consecutively taken samples from the same production batch, data are shown in Table 2. Although for all substrate ingredients and the substrate mixture, an acidic $\mathrm{pH}$ equal or below 5.11 was measured, the $\mathrm{pH}$ of the frass showed a higher $\mathrm{pH}$ of $8.05 \pm 0.07$. Compared to Experiment 1, the protein kibbles showed a statistically significant lower value in water activity $\left(\mathrm{a}_{\mathrm{w}}=0.54 \pm 0.00, P<0.001\right)$ and moisture content $(12.2 \pm 0.3 \%$, $P<0.001$ ), but even though the difference was statistically significant, it is thought not to have a major impact during the rearing practice. Despite the fact that the frass showed the same water activity as the substrate ingredients and mixture $\left(\mathrm{a}_{\mathrm{w}}=0.97 \pm 0.00\right)$, with exception of the protein kibbles $\left(\mathrm{a}_{\mathrm{w}}=0.54 \pm 0.00\right)$, a lower moisture content of $36.4 \pm 0.4 \%$ was observed for the frass. Both fresh larvae samples (starter and harvested larvae) did not differ in $\mathrm{pH}$ $(\mathrm{pH}=6.05 \pm 0.03$ and $6.13 \pm 0.01$ respectively, $P=0.060)$ or water activity $\left(\mathrm{a}_{\mathrm{w}}=0.97 \pm 0.0, P=0.999\right)$, while the moisture content of starter larvae $(62.7 \pm 0.7 \%)$ was slightly (but significantly) lower than for harvested larvae $(67.7 \pm 0.1 \%)$ $(P<0.001)$. Furthermore, the drying process resulted in a lower $\mathrm{pH}(6.77 \pm 0.01)$, water activity $(0.08 \pm 0.02)$ and moisture content $(0.9 \pm 0.0 \%)$ for dried larvae, compared to the harvested larvae. Also between the two types of dried larvae samples (immediately after drying and dried and then stored) a difference in water activity and moisture content was recorded, with the highest values for stored dried larvae $\left(\mathrm{a}_{\mathrm{w}}=0.27 \pm 0.08\right.$, moisture content $\left.=3.0 \pm 0.1 \%\right)$. This indicates that immediately after drying, the larvae are very hygroscopic and can take up moisture during storage, but moisture uptake was only limited and the water activity remained far below the water activity value of 0.60 that allows microbial growth. No significant difference was observed for the $\mathrm{pH}(P=0.535)$ between the two larvae sample types.

Table 1. Intrinsic parameters and microbial counts obtained in Experiment 1. Results are presented as the average of three replicates \pm standard deviation.

\begin{tabular}{|c|c|c|c|c|c|c|c|}
\hline \multirow[b]{2}{*}{ Sample } & \multicolumn{3}{|c|}{ Intrinsic parameters } & \multicolumn{4}{|c|}{ Microbial counts (log cfu/g) } \\
\hline & $\mathrm{pH}(-)$ & $a_{w}(-)$ & $\begin{array}{l}\text { Moisture } \\
\text { content (\%) }\end{array}$ & $\begin{array}{l}\text { Total viable } \\
\text { count }\end{array}$ & $\begin{array}{l}\text { Aerobic } \\
\text { endospores }\end{array}$ & $\begin{array}{l}\text { Total } \\
\text { Clostridium } \\
\text { perfringens }\end{array}$ & $\begin{array}{l}\text { Clostridium } \\
\text { perfringens } \\
\text { endospores }\end{array}$ \\
\hline Potato starch & $3.55 \pm 0.05^{b}$ & $0.97 \pm 0.00^{c}$ & $81.3 \pm 0.0^{c}$ & $4.8 \pm 0.0^{\mathrm{a}}$ & $3.8 \pm 0.0^{b}$ & $2.3 \pm 0.3^{c}$ & $1.4 \pm 0.1^{b}$ \\
\hline WPPP2 & $3.10 \pm 0.02^{\mathrm{a}}$ & $0.97 \pm 0.00^{c}$ & $80.4 \pm 1.4^{c}$ & $5.3 \pm 0.0^{\mathrm{a}}$ & $2.3 \pm 0.1^{a}$ & $<1.2 \pm 0.5^{b}$ & $<1.0 \pm 0.0^{\mathrm{a}}$ \\
\hline Protein kibbles & $5.02 \pm 0.02^{c}$ & $0.56 \pm 0.00^{b}$ & $10.9 \pm 0.1^{b}$ & $4.3 \pm 0.3^{a}$ & $3.6 \pm 0.3^{b}$ & $2.0 \pm 0.0^{c}$ & $1.3 \pm 0.3^{b}$ \\
\hline Dried larvae & $6.90 \pm 0.01^{d}$ & $0.22 \pm 0.01^{a}$ & $2.1 \pm 0.0^{\mathrm{a}}$ & $4.3 \pm 0.7^{a}$ & $3.9 \pm 0.1^{b}$ & $<1.0 \pm 0.0^{\mathrm{a}}$ & $<1.0 \pm 0.0^{\mathrm{a}}$ \\
\hline
\end{tabular}


Table 2. Intrinsic parameters and microbial counts obtained in Experiment 2. Results are presented as the average of three replicates \pm standard deviation. ${ }^{1}$

\begin{tabular}{|c|c|c|c|c|c|c|c|}
\hline \multirow[b]{2}{*}{ Sample } & \multicolumn{3}{|c|}{ Intrinsic parameters } & \multicolumn{4}{|c|}{ Microbial counts (log cfu/g) } \\
\hline & $\mathrm{pH}(-)$ & $a_{w}(-)$ & $\begin{array}{l}\text { Moisture } \\
\text { content (\%) }\end{array}$ & $\begin{array}{l}\text { Total viable } \\
\text { count }\end{array}$ & $\begin{array}{l}\text { Aerobic } \\
\text { endospores }\end{array}$ & $\begin{array}{l}\text { Total } \\
\text { Clostridium } \\
\text { perfringens }\end{array}$ & $\begin{array}{l}\text { Clostridium } \\
\text { perfringens } \\
\text { endospores }\end{array}$ \\
\hline Potato starch & $3.77 \pm 0.01^{c}$ & $0.97 \pm 0.00^{d}$ & $73.0 \pm 0.1^{h}$ & $5.8 \pm 0.0^{d}$ & $4.1 \pm 0.0^{\mathrm{e}}$ & $3.0 \pm 0.1^{\mathrm{e}}$ & $2.5 \pm 0.1^{d}$ \\
\hline WPPP2 2 & $3.24 \pm 0.02^{\mathrm{a}}$ & $0.97 \pm 0.00^{d}$ & $82.9 \pm 0.3^{i}$ & $5.3 \pm 0.0^{c}$ & $2.2 \pm 0.1^{a}$ & $2.1 \pm 0.4^{\mathrm{c}, \mathrm{d}}$ & $<1.0 \pm 0.0^{a}$ \\
\hline Protein kibbles & $5.11 \pm 0.04^{d}$ & $0.54 \pm 0.00^{c}$ & $12.2 \pm 0.3^{c}$ & $5.1 \pm 0.4^{b, c}$ & $3.0 \pm 0.5^{b, c}$ & $1.6 \pm 0.1^{b}$ & $<1.0 \pm 0.0^{a}$ \\
\hline Substrate mixture & $3.65 \pm 0.02^{b}$ & $0.97 \pm 0.00^{d}$ & $68.9 \pm 0.1^{9}$ & $4.9 \pm 0.1^{b, c}$ & $3.9 \pm 0.1^{\mathrm{d}, \mathrm{e}}$ & $1.7 \pm 0.3^{b, c}$ & $1.7 \pm 0.1^{\mathrm{c}}$ \\
\hline Starter larvae & $6.05 \pm 0.03^{e}$ & $0.97 \pm 0.00^{d}$ & $62.7 \pm 0.7^{e}$ & $9.5 \pm 0.19$ & $2.5 \pm 0.1^{a, b}$ & $<1.0 \pm 0.0^{\mathrm{a}}$ & $<1.0 \pm 0.0^{a}$ \\
\hline Harvested larvae & $6.13 \pm 0.01^{\mathrm{e}}$ & $0.97 \pm 0.00^{d}$ & $67.7 \pm 0.1^{f}$ & $8.2 \pm 0.1^{e}$ & $3.2 \pm 0.1^{b, c, d}$ & $<1.0 \pm 0.0^{a}$ & $<1.0 \pm 0.0^{\mathrm{a}}$ \\
\hline Residue & $8.05 \pm 0.079$ & $0.97 \pm 0.00^{d}$ & $36.4 \pm 0.4^{d}$ & $8.7 \pm 0.1^{f}$ & $5.0 \pm 0.1^{f}$ & $2.2 \pm 0.1^{d}$ & $1.5 \pm 0.1^{b}$ \\
\hline Dried larvae & $6.77 \pm 0.01^{f}$ & $0.08 \pm 0.02^{\mathrm{a}}$ & $0.9 \pm 0.0^{\mathrm{a}}$ & $4.3 \pm 0.2^{\mathrm{a}}$ & $3.3 \pm 0.5^{c, d}$ & $<1.0 \pm 0.0^{\mathrm{a}}$ & $<1.0 \pm 0.0^{a}$ \\
\hline Stored dried larvae & $6.72 \pm 0.01^{f}$ & $0.27 \pm 0.08^{b}$ & $3.0 \pm 0.1^{b}$ & $4.7 \pm 0.1^{a, b}$ & $2.9 \pm 0.0^{b, c}$ & $<1.0 \pm 0.0^{a}$ & $<1.0 \pm 0.0^{a}$ \\
\hline
\end{tabular}

${ }^{1}$ Means of samples with the same letter in superscript within the same column do not differ significantly $(P \geq 0.05)$.

${ }^{2}$ WPPP $=$ wheat and potato processing product.

In addition to the intrinsic parameters, the microbial counts also indicated differences among the samples. All substrate ingredients (potato starch, WPPP and protein kibbles) showed a total viable count between $5.1 \pm 0.4$ and $5.8 \pm 0.0 \mathrm{log}$ $\mathrm{cfu} / \mathrm{g}$ and an endospore count between $2.2 \pm 0.1$ and $4.1 \pm 0.0$ $\log \mathrm{cfu} / \mathrm{g}$. For the substrate mixture, a comparable total viable count of $4.9 \pm 0.1 \mathrm{cfu} / \mathrm{g}$ and endospore count of $3.9 \pm 0.1$ $\log \mathrm{cfu} / \mathrm{g}$ was recorded. The residue showed a statistically significant increase compared to the substrate mixture, to $8.7 \pm 0.1 \log \mathrm{cfu} / \mathrm{g}$ for the total viable count $(P<0.001)$ and to $5.0 \pm 0.1 \log \mathrm{cfu} / \mathrm{g}$ for the endospore count $(P<0.001)$. For the living larvae samples, the total viable count of the starter larvae was high $(9.5 \pm 0.1 \mathrm{log} \mathrm{cfu} / \mathrm{g})$ and substantially decreased to $8.2 \pm 0.1 \log \mathrm{cfu} / \mathrm{g}$ in the harvested larvae. For aerobic endospores, no statistically significant increase or decrease was observed between the two types of living larvae samples $(P=0.060)$, which showed values of $2.5 \pm 0.1$ and $3.2 \pm 0.1 \log \mathrm{cfu} / \mathrm{g}$ for starter larvae and harvested larvae, respectively. The drying process of the larvae caused the total viable counts to decrease by $3.9 \log$ cycles, and hence the counts of the dried larvae $(4.3 \pm 0.2 \mathrm{log} \mathrm{cfu} / \mathrm{g})$ differed in a significant way $(P<0.001)$ from those of the harvested larvae. On the other hand, the endospore counts of the dried larvae $(3.3 \pm 0.5 \log \mathrm{cfu} / \mathrm{g})$ did not differ significantly from the values observed for the harvested larvae $(P=0.999)$. As could be expected, in the total microbial community of vegetative cells and spores, the latter survived the drying process the best. Storage of the dried larvae did not cause an evolution in the microbial load.

Table 2 also includes values on the total and endospore counts of $C$. perfringens in the investigated samples. All substrate ingredients, as well as the substrate mixture, show values slightly above the detection limit of $1.0 \pm 0.0 \mathrm{log}$ $\mathrm{cfu} / \mathrm{g}$ for total C. perfringens counts. As to C. perfringens endospores, only for potato starch and the substrate mixture the counts were (slightly) above $1.0 \pm 0.0 \mathrm{log} \mathrm{cfu} / \mathrm{g}$, with a higher count for potato starch $(2.5 \pm 0.1 \mathrm{log} \mathrm{cfu} / \mathrm{g})$ than for the substrate mixture $(1.7 \pm 0.1 \log \mathrm{cfu} / \mathrm{g})$. Although the residue showed the presence of the pathogen in values of $2.2 \pm 0.1$ and $1.5 \pm 0.1 \log \mathrm{cfu} / \mathrm{g}$ for total and endospore counts, respectively, no C. perfringens was counted above the detection limit for the living larvae samples. Also after the drying process, the pathogen counts were still below $1.0 \pm 0.0 \log \mathrm{cfu} / \mathrm{g}$.

\section{Discussion}

In this study, the general microbiological quality as well as the quantity of $C$. perfringens were monitored in different parts of an industrial production process of dried BSFL. A first experiment (Experiment 1) demonstrated that the presence of $C$. perfringens in ingredients used to make up the final rearing substrate is possible. As mentioned before, all substrate ingredients were commercially available GMP+ certified feed products. They are frequently used in the broad animal feed industry, and not in particular for insect production. Results from Experiment 2 confirmed the finding of Experiment 1, and also uncovered a difference in the presence of vegetative cells of $C$. perfringens and its endospores. Bernard et al. (2020) also mentioned the possible presence of $C$. perfringens in rearing substrates for BSFL, but they indicated the prevalence as very rare. On the other hand, in other studies (Raimondi et al., 2020; 
Wynants et al., 2019), no Clostridium was detected in any of the substrates. As mentioned by Vandeweyer et al. (2021), insect rearing substrates are often pre-treated before feeding to the larvae to reduce the bacterial load. Also in this case study, substrates were pre-treated by acidification or fermentation (for potato starch and WPPP) or drying (for protein kibbles) to control the bacterial load and extend the storage time of the substrates. These pre-treatments could not avoid the presence of the pathogen, but at least when fermenting the substrates, the $\mathrm{pH}$ is reduced and can be expected to be low enough to prevent germination of spores and growth of vegetative cells. For instance, Valero et al. (2020) demonstrated for a cocktail of a related species, $C$. sporogenes, that spores could not germinate at a pH below 5.0. Mohammad et al. (2020) demonstrated that acidification of cooked rice to a $\mathrm{pH}$ of 4.2 inhibited growth of C. perfringens, even when the rice was kept at room temperature for $24 \mathrm{~h}$. Indeed, for optimal growth, C. perfringens requires a $\mathrm{pH}$ of 6.0 to 7.0 (Juneja et al., 2013; Paredes-Sabja et al., 2008).

Also for the larvae, noteworthy observations were made. The total viable counts were much higher for the starter larvae $(9.5 \pm 0.1 \log \mathrm{cfu} / \mathrm{g})$ than for the substrate on which they were reared $(4.9 \pm 0.1 \log \mathrm{cfu} / \mathrm{g})$. The counts slightly decreased towards harvesting time $(8.2 \pm 0.1 \mathrm{log} \mathrm{cfu} / \mathrm{g})$. At harvest, they were comparable to the counts of the residue $(8.7 \pm 0.1 \log \mathrm{cfu} / \mathrm{g})$. While the difference in counts between harvested larvae and residue was statistically different, from a microbiological perspective this difference is not very large. These findings coincide with those of Wynants et al. (2019), who studied the bacterial community of four laboratory-scale and three large-scale facility black soldier fly rearing cycles on different waste streams. The authors reported a significant reduction in the total viable count of larvae during rearing and observed the total viable count ranging from 8.0 to $9.8 \mathrm{log} \mathrm{cfu} / \mathrm{g}$ for larvae at harvest. On the other hand, Wynants et al. (2019) reported higher aerobic endospores counts (3.7-7.5 $\log \mathrm{cfu} / \mathrm{g}$ ) for harvested larvae than values obtained in this experiment $(3.2 \pm 0.1 \log \mathrm{cfu} / \mathrm{g})$. This variation in endospore counts can indicate that this microbial subgroup is characterised by a broader range in its quantitative occurrence than total aerobic counts. Although several studies (Defilippo et al., 2018; Erickson et al., 2004; Swinscoe et al., 2020) demonstrated a horizontal transfer of pathogens from the substrate to the larvae during the rearing process, the larvae did not pick up C. perfringens from the substrate in this experiment. Horizontal transfer of pathogens from substrate to larvae can be substrate and/or species dependent, which is also proposed by Osimani and Aquilanti (2021). Because in this experiment only one batch of living larvae was analysed, more experiments should be performed to confirm these assumptions. In this study, C. perfringens was detected in the substrate, but its counts were below the detection limit for all larvae samples, while the opposite situation was observed by Raimondi et al. (2020). The authors observed the presence of $C$. perfringens (0.8-1.6 log cfu/g) in the prepupal stage of BSFL grown on a substrate that did not contain the pathogen. However, in general, information on contamination with C. perfringens is still scarce for the BSFL rearing process. For other insect species, studies on the prevalence of Clostridium spp., including C. perfringens, are more frequent. Review studies of Cappelli et al. (2020), Garofalo et al. (2019), Kooh et al. (2019), Murefu et al. (2019) and Vandeweyer et al. (2021) indicate that species of the genus Clostridium are regularly observed in insect species such as mealworms, crickets and locusts, and they report this to be an important point of attention for the sector.

The residue, which consists of organic matter that passed through the larval gut (insect faeces), unconsumed substrate and exuviae (Houben et al., 2020), was characterised by a higher total viable count $(8.7 \pm 0.1 \mathrm{log} \mathrm{cfu} / \mathrm{g})$ and aerobic endospore count $(5.0 \pm 0.1 \mathrm{cfu} / \mathrm{g})$ than the substrate before feeding. Similarly, Wynants et al. (2019) reported a range of 8.5 to $10.2 \log \mathrm{cfu} / \mathrm{g}$ for the total viable count and a range of 4.2 to $7.0 \mathrm{log} \mathrm{cfu} / \mathrm{g}$ for the aerobic endospores for the residue at the time of harvest. In addition, in our experiment the residue was still contaminated with C. perfringens, both with vegetative cells and endospores. The presence of $C$. perfringens in the residue was also noticed in the study of Wynants et al. (2019), but only for one of the laboratory-scale rearing cycles. The lasting presence of the pathogen can be an indication that BSFL are not able to reduce pathogen load for $C$. perfringens under the rearing conditions used in the commercial facility considered in this study. In contrast, other studies (Erickson et al., 2004; Lalander et al., 2013, 2015; Liu et al., 2008; Lopes et al., 2020) showed a reducing effect for specific pathogens by BSFL. An important remark regarding the above-mentioned studies is that the pathogen-reducing effect only has been proven for specific Enterobacteriaceae species (Escherichia coli and Salmonella spp.) and lactic acid bacteria (Enterococcus spp.). In addition, the larvae were grown in different types of manure or aquaculture waste, and studied as potential waste processing treatment. They were not grown to produce a feed ingredient, as in our study. Another aspect that may influence the potential of the larvae to reduce the counts of a specific pathogen in their substrate, is the ratio of larvae to the amount of substrate used. This factor has not been investigated yet, but it is possible that in our study C. perfringens is reduced by the larvae, but that the ratio of larvae to substrate applied in the company is too low to show a significant pathogen reduction. As mentioned by Vandeweyer et al. (2021), more studies have to be performed to unravel the pathogen-reducing effects of BSFL and the potential substrate-dependency of these effects. Insect residue has a large potential to be used as organic soil fertiliser (Lohri et al., 2017; Poveda, 2021), but the presence of (food) pathogens, such as C. perfringens, is a point of 
attention. There may eventually be a need for treatments that reduce harmful organisms, such as a heat treatment. Research is needed on insect residue (and ongoing in our laboratory) to find out what the effect of heat (and other) treatments is on pathogens potentially present in the frass.

In the last production step, the drying process of the harvested larvae resulted in a reduction of the total viable count by $3.9 \log$ cycles, while the aerobic endospore count was not influenced. Because of the high temperature of $125^{\circ} \mathrm{C}$, which was applied on the harvested larvae for 45 minutes, a large part of the vegetative bacteria was killed, while bacterial endospores were not eliminated. This can be explained by the extreme resistance to heat of bacterial endospores (Talukdar et al., 2017; Vandeweyer et al., 2020). In this experiment $C$. perfringens was already below the detection limit for harvested larvae, and therefore the potential reducing effect of the drying process applied by the producer on the total C. perfringens and the C. perfringens spores could not be evaluated. $C$. perfringens endospores have a decimal reduction time (D-value) of $1.9 \mathrm{~min}$ at $100{ }^{\circ} \mathrm{C}$ and a z-value of $8.3^{\circ} \mathrm{C}$ (Byrne et al., 2006). This means that a treatment of $1.9 \mathrm{~min}$ at $100{ }^{\circ} \mathrm{C}$ is necessary to reduce spore counts by one log cycle (implied by the $\mathrm{D}$-value) and that the treatment temperature should be increased with $8.3^{\circ} \mathrm{C}$ to lower the treatment time tenfold and still obtain the same reduction (implied by the $\mathrm{z}$-value). The question can be raised whether it is possible, or even necessary, to implement treatments that completely eliminate the spores. As long as the intrinsic parameters of the matrix do not allow spore germination, it can be argued that a certain amount of spores could be tolerated, but the next question is then what that amount can be. At this moment, there are no criteria for $C$. perfringens other than that it should be absent in $1 \mathrm{~g}$ product samples taken directly after treatment when 'method 7' is applied (Regulation (EC) No 142/2011), as mentioned earlier. To determine a certain level of spores that can be tolerated is very difficult, or even impossible, since it would require introducing samples of treated larvae with a range of spore counts into the further feed and food chain, monitoring numbers of C. perfringens in the rest of the chain, and assess the risk of these numbers to cause health problems (only large amounts of vegetative cells in food products cause disease, see introduction). The behaviour of C. perfringens in the rest of the chain will be highly dependent on the different steps in the production chain and whether these steps allow germination of the spores and growth of the vegetative cells. While the intrinsic parameters of the BSFL as finished product may prevent spore germination, once the larvae are included in an animal feed and in this way diluted with other matrices, the conditions with respect to microbial growth may change and no longer prevent spore germination. Moreover, heat treatments that do not kill spores, may have an activating effect on the spores and trigger them to germinate (Vandeweyer et al., 2021). This can be the heat treatment applied on the larvae at the end of the BSFL production process, but this can also be a heat treatment applied on an animal feed that contains BSFL during pelleting or crumble production of that feed. This is another element that discourages the use of a certain tolerance for the presence of C. perfringens in BSFL as feed ingredient.

The storage conditions for the processed insects should prevent endospore germination and vegetative cell growth (Kooh et al., 2019). In this experiment, no increase in microbial counts was observed during storage of the dried larvae, indicating that the heat treatment achieved sufficient microbial reduction and that storage conditions were appropriate. If further processing of dried larvae is required, post-contamination can occur, for instance via personnel or by contact with contaminated equipment or surfaces. This post-contamination should be avoided by applying good hygiene practices (IPIFF, 2019).

\section{Conclusion}

This study delivered some insight in the general microbiological quality and the occurrence of C. perfringens vegetative cells and spores throughout different steps in the industrial production process of dried BSFL. This is a preliminary, observational study and the conclusion is related to a single facility and two time points. C. perfringens vegetative cells and endospores were present in some of the ingredient samples, even though they were GMP+ certified, and in the substrate investigated. The larvae showed a high overall microbial load, but there was no transmission of $C$. perfringens from the substrate to the larvae in this study. The residue, however, was still contaminated with C. perfringens. The heat treatment of the larvae considerably reduced their microbial load. In the production batches monitored in this study, safe larvae were produced with respect to $C$. perfringens, but generally we recommend to monitor this and other food safety pathogens from time to time, to make sure that their levels do not rise unnoticed. Furthermore, it goes without saying that good hygiene practices are important.

\section{Acknowledgements}

DV is financed by the Research Foundation - Flanders (FWO) via the SBO project ENTOBIOTA (S008519N) as well as by the European Union's Horizon 2020 Research and Innovation programme via the $\mathrm{H} 2020$ project SUSINCHAIN (grant agreement number 861976). NVL is PhD researcher on the ERANET FACCE SURPLUS project UpWaste (ID 28) funded by FWO.

\section{Conflict of interest}

The authors declare no conflict of interest. 


\section{References}

Bagge, E., Persson, M. and Johansson, K.E., 2010. Diversity of sporeforming bacteria in cattle manure, slaughterhouse waste and samples from biogas plants. Journal of Applied Microbiology 109: 1549-1565. https://doi.org/10.1111/j.1365-2672.2010.04790.x

Bernard, E., Villazana, J., Alyokhin, A. and Rose, J., 2020. Colonisation of finfish substrate inhabited by black soldier fly larvae by blow flies, bacteria, and fungi. Journal of Insects as Food and Feed 6: 291-304. https://doi.org/10.3920/jiff2019.0044

Byrne, B., Dunne, G. and Bolton, D.J.Ã., 2006. Thermal inactivation of Bacillus cereus and Clostridium perfringens vegetative cells and spores in pork luncheon roll. Food Microbiology 23: 803-808. https://doi.org/10.1016/j.fm.2006.02.002

Cappelli, A., Cini, E., Lorini, C., Oliva, N. and Bonaccorsi, G., 2020. Insects as food: a review on risks assessments of Tenebrionidae and Gryllidae in relation to a first machines and plants development. Food Control 108: 106877. https://doi.org/10.1016/j. foodcont.2019.106877

Defilippo, F., Grisendi, A., Listorti, V., Dottori, M. and Bonilauri, P., 2018. Black soldier fly larvae reared on contaminated substrate by Listeria monocytogenes and Salmonella. Available at: https:// meetings.eaap.org/wp-content/uploads/2018/Session47/47.16_ aq9i52ws.pdf

Diener, S., Zurbrügg, C. and Tockner, K., 2009. Conversion of organic material by black soldier fly larvae: establishing optimal feeding rates. Waste Management and Research 27: 603-610. https://doi. org/10.1177/0734242X09103838

Dijk, R., Van den Berg, D., Beumer, R., De Boer, E., Dijkstra, A., Mout, L., Stegeman, M., Uyttendaele, M. and In 't Veld, S., 2015. Microbiologie van de voedingsmiddelen: methoden, principes en criteria. MYbusinessmedia, Rotterdam, the Netherlands, 688 pp.

Erickson, M.C., Islam, M., Sheppard, C., Liao, J. and Doyle, M.P., 2004. Reduction of Escherichia coli O157:H7 and Salmonella enterica serovar enteritidis in chicken manure by larvae of the black soldier fly. Journal of Food Protection 67: 685-690. https:// doi.org/10.4315/0362-028X-67.4.685

European Commission (EC), 2001. Regulation (EC) No 999/2001 of the European Parliament and of the Council of 22 May 2001 laying down rules for the prevention, control and eradication of certain transmissible spongiform encephalopathies. Official Journal L 147: 1-40. Available at: http://data.europa.eu/eli/reg/2001/999/oj

European Commission (EC), 2011. Commission Regulation (EU) No 142/2011 of 25 February 2011 implementing Regulation (EC) No 1069/2009 of the European Parliament and of the Council laying down health rules as regards animal by-products and derived products not intended for human consumption and implementing Council Directive 97/78/EC as regards certain samples and items exempt from veterinary checks at the border under that Directive. Official Journal L 54: 1-254.

European Commission (EC), 2017. Commission Regulation (EU) No $2017 / 893$ of 24 May 2017 as regards the provisions on processed animal protein. Official Journal L 138: 92-116.
Filippidou, S., Junier, T., Wunderlin, T., Lo, C.C., Li, P.E., Chain, P.S. and Junier, P., 2015. Under-detection of endospore-forming Firmicutes in metagenomic data. Computational and Structural Biotechnology Journal 13: 299-306. https://doi.org/10.1016/j.csbj.2015.04.002

Garofalo, C., Milanović, V., Cardinali, F., Aquilanti, L., Clementi, F. and Osimani, A., 2019. Current knowledge on the microbiota of edible insects intended for human consumption: a state-of-theart review. Food Research International 125: 108527. https://doi. org/10.1016/j.foodres.2019.108527

Grenda, T., Kwiatek, K., Goldsztejn, M., Sapała, M., Kozieł, N. and Domaradzki, P., 2021. Clostridia in insect processed animal proteins - is an epidemiological problem possible? Agriculture 11: 270. https://doi.org/10.3390/agriculture11030270

Houben, D., Daoulas, G., Faucon, M.P. and Dulaurent, A.M., 2020. Potential use of mealworm frass as a fertilizer: impact on crop growth and soil properties. Scientific Reports 10, Article number: 4659. https://doi.org/10.1038/s41598-020-61765-x

International Platform of Insects for Food and Feed (IPIFF), 2019. IPIFF guide on good hygiene practices for European Union producers of insects as food and feed. IPIFF, Brussels, Belgium, 108 pp. Available at: https://ipiff.org/wp-content/uploads/2019/12/IPIFF-Guide-onGood-Hygiene-Practices.pdf

International Platform of Insects for Food and Feed (IPIFF), 2021. Insects EU legislation. IPIFF, Brussels, Belgium. Available at: https:// ipiff.org/insects-eu-legislation/

Jiang, C.L., Jin, W.Z., Tao, X.H., Zhang, Q., Zhu, J., Feng, S.Y., Xu, X.H., Li, H.Y., Wang, Z.H. and Zhang, Z.J., 2019. Black soldier fly larvae (Hermetia illucens) strengthen the metabolic function of food waste biodegradation by gut microbiome. Microbial Biotechnology 12: 528-543. https://doi.org/10.1111/1751-7915.13393

Joosten, L., Lecocq, A., Jensen, A.B., Haenen, O., Schmitt, E. and Eilenberg, J., 2020. Review of insect pathogen risks for the black soldier fly (Hermetia illucens) and guidelines for reliable production. Entomologia Experimentalis et Applicata 168: 432-447. https://doi. org/10.1111/eea.12916

Juneja, V.K., Novak, J.S. and Labbe, R.J., 2010. Clostridium perfringens. In: Juneja, V.K. and Sofos, J.N. (eds.) Pathogens and toxins in food: challenges and interventions. ASM Press, Washington, DC, USA, pp. 53-70.

Juneja, V.K., Baker, D.A., Thippareddi, H., Snyder, O.P. and Mohr, T.B., 2013. Growth potential of Clostridium perfringens from spores in acidified beef, pork, and poultry products during chilling. Journal of Food Protection 76: 65-71. https://doi.org/10.4315/0362-028X. JFP-12-289

Kooh, P., Ververis, E., Tesson, V., Boué, G. and Federighi, M., 2019. Entomophagy and public health: a review of microbiological hazards. Health 11: 1272-1290. https://doi.org/10.4236/health.2019.1110098 Lalander, C.H., Diener, S., Magri, M.E., Zurbrügg, C., Lindström, A. and Vinnerås, B., 2013. Faecal sludge management with the larvae of the black soldier fly (Hermetia illucens) - from a hygiene aspect. Science of the Total Environment 458-460: 312-318. https://doi. org/10.1016/j.scitotenv.2013.04.033 
Lalander, C.H., Fidjeland, J., Diener, S., Eriksson, S. and Vinnerås, B., 2015. High waste-to-biomass conversion and efficient Salmonella spp. reduction using black soldier fly for waste recycling. Agronomy for Sustainable Development 35: 261-271. https://doi.org/10.1007/ s13593-014-0235-4

Li, J., Paredes-Sabja, D., Sarker, M.R. and McClane, B.A., 2016. Clostridium perfringens sporulation and sporulation-associated toxin production. The Bacterial Spore 4: 331-347. https://doi. org/10.1128/9781555819323.ch16

Lievens, S., Poma, G., De Smet, J., Van Campenhout, L., Covaci, A. and Van der Borght, M., 2021. Chemical safety of black soldier fly larvae (Hermetia illucens), knowledge gaps and recommendations for future research: a critical review. Journal of Insects as Food and Feed 7(4): 383-396. https://doi.org/10.3920/JIFF2020.0081

Liu, Q., Tomberlin, J.K., Brady, J.A., Sanford, M.R. and Yu, Z., 2008. Black soldier fly (Diptera: Stratiomyidae) larvae reduce Escherichia coli in dairy manure. Environmental Entomology 37: 1525-1530. https://doi.org/10.1603/0046-225X-37.6.1525

Lohri, C.R., Diener, S., Zabaleta, I., Mertenat, A. and Zurbrügg, C., 2017. Treatment technologies for urban solid biowaste to create value products: a review with focus on low- and middle-income settings. Reviews in Environmental Science and Biotechnology 16: 81-130. https://doi.org/10.1007/s11157-017-9422-5

Lopes, I.G., Lalander, C., Vidotti, R.M. and Vinnerås, B., 2020. Reduction of bacteria in relation to feeding regimes when treating aquaculture waste in fly larvae composting. Frontiers in Microbiology 11: 1616. https://doi.org/10.3389/fmicb.2020.01616

Makkar, H.P.S., Tran, G., Heuzé, V. and Ankers, P., 2014. Stateof-the-art on use of insects as animal feed. Animal Feed Science and Technology 197: 1-33. https://doi.org/10.1016/j. anifeedsci.2014.07.008

McNamara, A. and Lattuade, C., 1998. Examination of meat and poultry products for Clostridium perfringens USDA/FSIS Microbiology Laboratory Guidebook. FSIS, Georgia, USA, 8 pp.

Meneguz, M., Gasco, L. and Tomberlin, J.K., 2018. Impact of pH and feeding system on black soldier fly (Hermetia illucens, L; Diptera: Stratiomyidae) larval development. PLoS ONE 13(8): e0202591. https://doi.org/10.1371/journal.pone.0202591

Mohammad, Z.H., Payton, L. and Sirsat, S.A., 2020. Efficacy of sushi rice acidification: quantification of Bacillus cereus and Clostridium perfringens during simulation of retail practices. LWT 131: 109884. https://doi.org/10.1016/j.lwt.2020.109884

Murefu, T.R., Macheka, L., Musundire, R. and Manditsera, F.A., 2019. Safety of wild harvested and reared edible insects: a review. Food Control 101: 209-224. https://doi.org/10.1016/j. foodcont.2019.03.003

Oonincx, D.G.A.B., Van Broekhoven, S., Van Huis, A. and Van Loon, J.J.A., 2015. Feed conversion, survival and development, and composition of four insect species on diets composed of food by-products. PLoS ONE 10: e0222043. https://doi.org/10.1371/ journal.pone.0144601

Osimani, A. and Aquilanti, L., 2021. Spore-forming bacteria in insectbased foods. Current Opinion in Food Science 37: 112-117. https:// doi.org/10.1016/j.cofs.2020.10.011
Paredes-Sabja, D., Torres, J.A., Setlow, P. and Sarker, M.R., 2008. Clostridium perfringens spore germination: characterization of germinants and their receptors. Journal of Bacteriology 190: 11901201. https://doi.org/10.1128/JB.01748-07

Poveda, J., 2021. Insect frass in the development of sustainable agriculture. A review. Agronomy for Sustainable Development 41: 5. https://doi.org/10.1007/s13593-020-00656-x

Raimondi, S., Spampinato, G., Macavei, L.I., Lugli, L., Candeliere, F., Rossi, M., Maistrello, L. and Amaretti, A., 2020. Effect of rearing temperature on growth and microbiota composition of Hermetia illucens. Microorganisms 8: 902. https://doi.org/10.3390/ microorganisms 8060902

R Development Core Team, 2020. R: a language and environment for statistical computing. R Foundation for Statistical Computing, Vienna, Austria.

Stamer, A., 2015. Insect proteins - a new source for animal feed. Science and Technology 16: 676-680. https://doi.org/10.15252/ embr.201540528

Swinscoe, I., Oliver, D.M., Ørnsrud, R. and Quilliam, R.S., 2020. The microbial safety of seaweed as a feed component for black soldier fly (Hermetia illucens) larvae. Food Microbiology 91: 103535. https:// doi.org/10.1016/j.fm.2020.103535

Talukdar, P.K., Udompijitkul, P., Hossain, A. and Sarker, M.F., 2017. Inactivation strategies for Clostridium perfringens spores and vegetative cells. Applied and Environmental Microbiology 83: e02731-16. https://doi.org/10.1128/AEM.02731-16

Valero, A., Olague, E., Medina-Pradas, E., Garrido-Fernández, A., Romero-Gil, V., Cantalejo, M.J., García-Gimeno, R.M., PérezRodríguez, F., Posada-Izquierdo, G.D. and Arroyo-López, F.N., 2020. Influence of acid adaptation on the probability of germination of Clostridium sporogenes spores against $\mathrm{pH}, \mathrm{NaCl}$ and time. Foods 9: 127. https://doi.org/10.3390/foods9020127

Vandeweyer, D., Lievens, B. and Van Campenhout, L., 2020. Identification of bacterial endospores and targeted detection of foodborne viruses in industrially reared insects for food. Nature Food 1: 511-516. https://doi.org/10.1038/s43016-020-0120-z

Vandeweyer, D., De Smet, J., Van Looveren, N. and Van Campenhout, L., 2021. Biological contaminants in insects as food and feed. Journal of Insects as Food and Feed 7(5): 807-822. https://doi.org/10.3920/ JIFF2020.0060

Wang, Y.-S. and Shelomi, M., 2017. Review of black soldier fly (Hermetia illucens) as animal feed and human food. Foods 6: 91. https://doi.org/10.3390/foods6100091

Wu, N., Wang, X., Xu, X., Cai, R. and Xie, S., 2020. Effects of heavy metals on the bioaccumulation, excretion and gut microbiome of black soldier fly larvae (Hermetia illucens). Ecotoxicology and Environmental Safety 192: 110323. https://doi.org/10.1016/j. ecoenv.2020.110323

Wynants, E., Frooninckx, L., Crauwels, S., Verreth, C., De Smet, J., Sandrock, C., Wohlfahrt, J., Van Schelt, J., Depraetere, S., Lievens, B., Van Miert, S., Claes, J. and Van Campenhout, L., 2019. Assessing the microbiota of black soldier fly larvae (Hermetia illucens) reared on organic waste streams on four different locations at laboratory and large scale. Microbial Ecology 77: 913-930. https://doi.org/10.1007/ s00248-018-1286-x 
